\title{
Genetic Variability, Heritability and Genetic Advance for Economic Root Traits in Asiatic and European Type Carrot Germplasm Lines (Daucus carota L.)
}

\author{
Chaitra C. Kulkarni, D.S. Manikanta, Chaitra A. Poleshi, Sarvamangala S. Cholin*, \\ G. Raghavendra, D.S. Ambika and B.B. Patil
}

Plant Molecular Biology Lab (DBT-BIOCARe), Department of Biotechnology \& Crop Improvement, College of Horticulture, Bagalkot-587104, Karnataka, India

*Corresponding author

Key w o r d s
Carrot, root traits
Genetic variability,
ANOVA,
Heritability,
Genetic advance
Article Info
$\begin{aligned} & \text { Accepted: } \\ & \text { 20 June } 2019 \\ & \text { Available Online: } \\ & \text { 10 July } 2019\end{aligned}$

\section{A B S T R A C T}

The present investigation was carried out to study the vvariability and heritability component estimates for different characters of carrot. The experimental material comprised of 96 genotypes of carrot and laid out in an augmented block design comprising of 3 checks (Ghataprabha Local, Vigro Kuruda and Pusa Vrishti) with 6 blocks to screen the genotypes comprising of European and Asiatic types with diverse colors at University of horticultural Sciences, Bagalkot during 2016-2017. Observations were recorded on 18 quantitative traits including root and plant morphological traits. Analysis of variance revealed highly significant differences among the genotypes for all the characters. Phenotypic coefficient of variation (PCV) was higher than the genotypic coefficient of variation (GCV) which indicates the role of environmental factors on the expression of various traits studied in the present investigation. Yield parameters like root weight, vegetative weight, harvest index possessed higher values of GCV, heritability and genetic gain. These are the most important traits for applying selection in carrot for crop improvement.

\section{Introduction}

Carrot (Daucus carota L.), an ancient cool season root vegetable, is a member of the family Apiaceae (Peirce, 1987). It is a diploid species having chromosome number of $2 n=18$, with a relatively small genome of $480 \mathrm{Mb}$ (Iorizzo et al., 2016). It is considered to be native of Afghanistan (Banga, 1976). Roots are used for making soups, stews, curries, pies, pickles and for salad purposes. Carotenoid composition determines the white, yellow, orange or red root colour in the carrot (Nicolle et al., 2004; Surles et al., 2004).

The biennial nature of carrot makes it a challenging crop for improvement. But being a highly cross pollinated species, with seed producing nature and its broad genetic base make this crop a great interest to a breeder. 
Heterosis can be very well exploited in terms of hybrids or by developing synthetics by combining superior inbreds having higher general combining ability (GCA). Inbreeding depression is the main draw back in inbred development. Among the carrot root morphology, uniformity in root shape, size, external root color (uniform orange), core size (small), internal color (uniform orange xylem and phloem) are some of the most important characters (Peterson and Simon, 1986; Rubatzky et al., 1999).

For initiating systematic breeding/ improvement programme in any crop, it is essential to study variability present in the basic genetic material/germplasm. Genetic variability in a root crop species is normally expected to be immense. In carrot, roots vary greatly in shape, size and other characteristics. Therefore, to enhance productivity, genetic restructuring of carrot germplasm is required to develop high yielding varieties with desired traits. Most of the desired traits are quantitative in nature and influenced by the environment for their expression. According to Fisher (1918), the quantitative traits exhibiting continuous variation are under the control of heritable and non-heritable factors. Greater the variability in a population for these traits, there are the greater chances for effective selection for desirable types (Vavilov, 1949). Phenotypic and genotypic coefficients of variation are useful in detecting amounts of variability present in germplasm. Response to selection depends on the relative proportion of the heritable component in the continuous variation (Singh and Mittal 2003). The heritable component is due to genotype, while the non-heritable portion is mainly due to the environmental factors. Assessment of the genotype is possible through assessment of the phenotypic expression, which is the result of genotypic and environmental interaction. Heritability estimates may not provide clear predictability of the breeding value. Thus, estimation of heritability accompanied with genetic advance is generally more useful than heritability alone in prediction of the resultant effect for selecting the best individuals (Johnson et al., 1955). The information on Asiatic carrots (tropical type) in India and probably abroad is very scanty because tropical types has not received ample attention for its genetic improvement. Therefore in the present study 96 germplasm lines representing both tropical and temperate types were evaluated in order to compare their genotypes for various horticulture traits, variability, heritability and genetic advance for various economic characters and incorporation these traits through breeding strategy.

\section{Materials and Methods}

The field experiment was conducted at Udyanagiri Campus of University of Horticultural Sciences, Bagalkot, Karnataka, India during 2016. Bagalkot is located in the northern region of Karnataka and positioned at $16^{\circ} 12^{\prime} \mathrm{N}, 75^{\circ} 45^{\prime} \mathrm{E}$ the average elevation in this area reaches approximately $610 \mathrm{~m}$. The climate is warm and dry throughout the year and rainfall is scarce with an average annual rainfall of $318 \mathrm{~mm}$ and belongs to semi-arid tropical region. Ninety six Daucus carota L. germplasm lines were used, including Asiatic and European cultivated accessions (Table 1). This panel represents a large diversity present in carrot especially for the colour viz., white, yellow, red, orange, Dark orange, purple and Black. The genotypes were collected from all over India, comprising of open-pollinated cultivars, local varieties, modern hybrid cultivars, released varieties. The experiment was laid out in Augmented block design comprising of 3 checks (Ghataprabha Local, Vigro Kuruda and Pusa Vrishti) with 6 blocks was utilized to screen the genotypes. For a healthy crop, appropriate standard and uniform cultural practices like thinning, weeding, hoeing, timely irrigations and plant 
protection measures were adopted. Observations were recorded 18 quantitative as mentioned in table 2. Ffifteen qualitative observations were recorded based on the IPGRI descriptor (IPGRI, 1998). Among biochemical parameters TSS was estimated using digital hand Refractometer and the values were recorded and expressed in ${ }^{0}$ Brix. Reducing sugars were estimated by following the Dinitrosalicylic acid (DNS) method given by Miller (1972). ß carotene was estimated as per the protocol of Harborne (1973). The analysis of variance (ANOVA) was carried out with the help of a software Windowstat (version 8.2). The phenotypic and genotypic coefficients of variation (PCV and GCV), were estimated by software Windowstat (version 8.2) and results were interpreted based on the following categorization as suggested by Sivasubramanian and Menon (1973). Heritability and GAM results based on formula given by Johnson et al., (1955) was used to interpret the results.

\section{Results and Discussion}

Analysis of variance revealed highly significant differences among the genotypes for all the characters viz. five plants root weight/five plants, five plants vegetative weight, root length, root diameter, plant height, leaf length, number of petioles per plant, days taken to marketable maturity, root width, shoulder width, xylem width, phloem width, harvest index, reducing sugars and carotene content which indicated that experimental material possessed good deal of variability for improvement (Table $3 a$ and $3 b$ ). These results are in consonance with the findings of Prasad and Prasad (1980), Gupta et. al., (2006) and Yadav et. al., (2009). The extent of variability present in the carrot genotypes was measured in terms of range, phenotypic coefficient of variation (PCV), genotypic coefficient of variation (GCV), heritability (broad sense) and expected genetic advance as per cent of mean (Table 4). High range was observed for all the character under study. Absolute variability in different characters cannot be considered as a critical factor for deciding as to which character is showing the highest degree of variability. The relative values of phenotypic and genotypic coefficients of variation, therefore, give an idea about the magnitude of variability present in a population since the estimate of genotypic variability, heritability and expected genetic advance are useful for crop improvement. The measure of genotypic co-efficient of variation is necessary to understand the role of environmental influence on different traits.

The phenotypic co-efficient of variation was slightly higher than genotypic co-efficient of variation for all the characters indicating the presence of environmental influences to some extent in the expression of the characters. Moderate to higher GCV and PCV was observed in most of the characters except TSS content and reducing sugars where GCV was lower although PCV was moderate indicating the role of environment/soil conditions/growth conditions on the expression of these traits. Yield parameters like single plant root weight and five plants root weight, vegetative weight and harvest index showed higher GCV as well as PCV indicating the existence of greater variation among these characters in the genotype panel selected for the present investigation. Similar results were also found by Tewatia and Dudi (1999) in carrot, Rabbani et al., (1998) in radish and Rahman et al., (2003) in tomato.

Genotypic co-efficient of variation does not give an idea of total variation that is heritable. Further, it may not be feasible to determine the amount of heritable variation and the relative degree to which a character is transmitted from parent to offspring, by the estimate of heritability. 
Table.1 Details of 96 carrot genotypes and their description

\begin{tabular}{|c|c|c|}
\hline Sl. No. & UHSBC-Nomenclature & Collection site \\
\hline 1 & UHSBC-1 & Local cultivar \\
\hline 2 & UHSBC-2 & Local cultivar \\
\hline 3 & UHSBC -3 & Local cultivar \\
\hline 4 & UHSBC-7 & Ooty collections \\
\hline 5 & UHSBC-14 & Local cultivar \\
\hline 6 & UHSBC-15 & Local cultivar \\
\hline 7 & UHSBC-16 & Local cultivar \\
\hline 8 & UHSBC-17 & Local cultivar \\
\hline 9 & UHSBC-18 & Local cultivar \\
\hline 10 & UHSBC-19 & Online Collection \\
\hline 11 & UHSBC-20 & Local cultivar \\
\hline 12 & UHSBC-21 & Local cultivar \\
\hline 13 & UHSBC-22 & Local cultivar \\
\hline 14 & UHSBC-23 & IIVR Collection \\
\hline 15 & UHSBC-23-1 & IIVR Collection \\
\hline 16 & UHSBC-24 & IIVR Collection \\
\hline 17 & UHSBC-25 & IIVR Collection \\
\hline 18 & UHSBC-26 & IIVR Collection \\
\hline 19 & UHSBC-27 & IIVR Collection \\
\hline 20 & UHSBC-28 & IIVR Collection \\
\hline 21 & UHSBC-29 & IIVR Collection \\
\hline 22 & UHSBC-30 & IIVR Collection \\
\hline 23 & UHSBC-31 & IIVR Collection \\
\hline 24 & UHSBC-32 & IIVR Collection \\
\hline 25 & UHSBC-32-2 & IIVR Collection \\
\hline 26 & UHSBC-33 & IIVR Collection \\
\hline 27 & UHSBC-34 & IIVR Collection \\
\hline 28 & UHSBC-34-1 & IIVR Collection \\
\hline 29 & UHSBC-34-2 & IIVR Collection \\
\hline 30 & UHSBC-35 & IIVR Collection \\
\hline 31 & UHSBC-36 & IIVR Collection \\
\hline 32 & UHSBC-37 & IIVR Collection \\
\hline 33 & UHSBC-38 & IIVR Collection \\
\hline 34 & UHSBC-39 & IIVR Collection \\
\hline 35 & UHSBC-40 & IIVR Collection \\
\hline 36 & UHSBC-41 & IIVR Collection \\
\hline 37 & UHSBC-41-1 & IIVR Collection \\
\hline 38 & UHSBC-42 & IIVR Collection \\
\hline 39 & UHSBC-43 & IIVR Collection \\
\hline 40 & UHSBC-43-1 & IIVR Collection \\
\hline 41 & UHSBC-44 & IIVR Collection \\
\hline 42 & UHSBC-45 & IIVR Collection \\
\hline 43 & UHSBC-46 & IIVR Collection \\
\hline 44 & UHSBC-47 & IIVR Collection \\
\hline 45 & UHSBC-48 & IIVR Collection \\
\hline 46 & UHSBC-49 & IIVR Collection \\
\hline 47 & UHSBC-50 & IIVR Collection \\
\hline 48 & UHSBC-51 & IIVR Collection \\
\hline
\end{tabular}




\begin{tabular}{|c|c|c|}
\hline Sl. No & UHSBC-Nomenclature & Collection Site \\
\hline 49 & UHSBC-52 & IIVR Collection \\
\hline 50 & UHSBC-53 & IIVR Collection \\
\hline 51 & UHSBC-54 & IIVR Collection \\
\hline 52 & UHSBC-55 & IIVR Collection \\
\hline 53 & UHSBC-56 & IIVR Collection \\
\hline 54 & UHSBC-58 & Temperate \\
\hline 55 & UHSBC-59 & Released Variety (IARI, New Delhi) \\
\hline 56 & UHSBC-63 & Released Variety (IARI) \\
\hline 57 & UHSBC-64 & Released Variety (IARI) \\
\hline 58 & UHSBC-65 & Released Variety (IARI) \\
\hline 59 & UHSBC-66 & Released Variety (IARI) \\
\hline 60 & UHSBC-67 & Released Variety (IARI) \\
\hline 61 & UHSBC-68 & Bangalore Market \\
\hline 62 & UHSBC-69 & Ooty collections \\
\hline 63 & UHSBC-71 & Local cultivar \\
\hline 64 & UHSBC-73 & Local cultivar \\
\hline 65 & UHSBC-76 & Local cultivar \\
\hline 66 & UHSBC-77 & Local cultivar \\
\hline 67 & UHSBC-78 & Local cultivar \\
\hline 68 & UHSBC-79 & Tamilanadu Collection-Temperate \\
\hline 69 & UHSBC-85 & Online collection \\
\hline 70 & UHSBC-89 & Tamilanadu Collection-Temperate \\
\hline 71 & UHSBC-90 & Online Collections \\
\hline 72 & UHSBC-92 & Online Collections \\
\hline 73 & UHSBC-93 & Online Collections \\
\hline 74 & UHSBC-94 & Online Collections \\
\hline 75 & UHSBC-95 & Collection from Farmer (Punjab Seeds) \\
\hline 76 & UHSBC-96 & Private Sector Seeds \\
\hline 77 & UHSBC-97 & Kodaikenal \\
\hline 78 & UHSBC-98 & Ooty Market (Private Sector Hybrid) \\
\hline 79 & UHSBC-99 & Tamilanadu Collection-Temperate \\
\hline 80 & UHSBC-100 & Ooty Market \\
\hline 81 & UHSBC-101 & Tamilanadu Collection-Temperate \\
\hline 82 & UHSBC-102 & Ooty Collections \\
\hline 83 & UHSBC-103 & Tamilanadu Collection-Temperate \\
\hline 84 & UHSBC-104 & Tamilanadu Collection-Temperate \\
\hline 85 & UHSBC-105 & Tamilanadu Collection-Temperate \\
\hline 86 & UHSBC-106 & Tamilanadu Collection-Temperate \\
\hline 87 & UHSBC-107 & Tamilanadu Collection-Temperate \\
\hline 88 & UHSBC-108 & Tamilanadu Collection-Temperate \\
\hline 89 & UHSBC-110 & Online Collection \\
\hline 90 & UHSBC-111 & Tamilanadu Collection-Temperate \\
\hline 91 & UHSBC-112 & Tamilanadu Seeds \\
\hline 92 & UHSBC-113 & Tamilanadu Collection-Temperate \\
\hline 93 & UHSBC-114 & Tamilanadu Collection-Temperate \\
\hline 94 & UHSBC-115 & Tamilanadu Collection-Temperate \\
\hline 95 & UHSBC-116 & North Indian-Temperate type \\
\hline 96 & UHSBC-117 & Local cultivar \\
\hline
\end{tabular}


Table.2a Analysis of variance (ANOVA) for 18 quantitative traits (Plant and root morphological traits and biochemical traits) in carrot by augmented design

\begin{tabular}{|c|c|c|c|c|c|c|c|c|c|c|}
\hline \multirow[t]{2}{*}{ Source of Variations } & \multirow[t]{2}{*}{ df } & \multicolumn{9}{|c|}{ Mean Sum Of Squares } \\
\hline & & DM & NP & SL & PH & $\mathbf{R L}$ & $\mathbf{P L}$ & RWD & SWD & VW \\
\hline $\begin{array}{l}\text { Block (Ignoring } \\
\text { Treatments) }\end{array}$ & 5 & $213.29 * *$ & $38.54 * * *$ & 0.06 & $242.16^{* *}$ & 18.19 & $26.60 * * *$ & 6.13 & $80.36 * *$ & $3838.60 * * *$ \\
\hline $\begin{array}{l}\text { Genotypes + Checks } \\
\text { (Eliminating Blocks) }\end{array}$ & 98 & $124.16^{* *}$ & $12.02 * * *$ & 0.05 & $89.58^{*}$ & $30.18 * *$ & $28.90 * * *$ & $10.89 * *$ & $39.33^{*}$ & $778.98 * * *$ \\
\hline Checks & 2 & 74.67 & 2.04 & 0.03 & $422.02 * *$ & 8.09 & $68.77 * * *$ & $29.61 * * *$ & $303.38 * * *$ & $537.59 *$ \\
\hline Checks +Gen vs. Gen. & 96 & $125.19 * *$ & $12.23 * * *$ & 0.05 & 82.66 & $30.64 * *$ & $28.07 * * *$ & $10.50 * * *$ & $33.83^{*}$ & $784.01 * * *$ \\
\hline Error & 10 & 20.8 & 0.66 & 0.02 & 31.92 & 7.41 & 2.43 & 1.92 & 11.79 & 104.34 \\
\hline $\begin{array}{l}\text { Block (eliminating } \\
\text { Check+ Genotypes) }\end{array}$ & 5 & $69.43^{*}$ & 0.99 & 0.02 & 25.90 & 6.03 & 3.57 & $9.39 *$ & 13.98 & 26.90 \\
\hline $\begin{array}{l}\text { Entries (Ignoring } \\
\text { Blocks) }\end{array}$ & 98 & $131.50 * *$ & $13.94 * * *$ & 0.05 & $100.62 *$ & $30.80 * *$ & $30.08 * * *$ & $10.72 * * *$ & $42.71 *$ & $973.46^{* * *}$ \\
\hline Checks & 2 & 74.67 & 2.04 & 0.03 & $422.02 * *$ & 8.09 & $68.77 * * *$ & $29.61 * * *$ & $303.38 * * *$ & $537.59 *$ \\
\hline Genotypes & 95 & $110.95 * *$ & $13.58 * * *$ & 0.05 & $89.24^{*}$ & $29.77 *$ & $29.28 * * *$ & $10.29 * *$ & $37.58^{*}$ & $920.14 * * *$ \\
\hline Checks vs. Genotypes & 1 & $\begin{array}{c}2197.92 * * \\
*\end{array}$ & $72.18 * * *$ & 0 & $538.87 * *$ & $173.44 * * *$ & $28.92 * *$ & $14.29 *$ & 9.03 & $6910.21 * * *$ \\
\hline Error & 10 & 20.8 & 0.66 & 0.02 & 31.92 & 7.41 & 2.43 & 1.92 & 11.79 & 104.34 \\
\hline
\end{tabular}

DM: Days to Maturity; NP: Number of Petioles; SL: Shoot Length; PH: Plant Height; RL: Root Length; PL: Petiole Length; RWD: Root Width, SWD: Shoot width; VW: Vegetative weight 
Table.3b Analysis of variance (ANOVA) for 18 quantitative

traits (Plant and root morphological traits and biochemical traits) in carrot

\begin{tabular}{|c|c|c|c|c|c|c|c|c|c|c|}
\hline \multirow{2}{*}{$\begin{array}{c}\text { Source of } \\
\text { Variations }\end{array}$} & \multirow[t]{2}{*}{ df } & \multicolumn{9}{|c|}{ Mean Sum of Squares } \\
\hline & & FPVW & XW & PW & HI & TSS & $\mathbf{R S}$ & Beta & $\mathbf{R W}$ & FPRW \\
\hline $\begin{array}{l}\text { Block (Ignoring } \\
\text { Treatments) }\end{array}$ & 5 & $57665.43 * * *$ & 0.08 & $0.03 * * *$ & $21.99 * * *$ & 2.22 & 0.49 & 827.25 & $264.02 *$ & 1860.41 \\
\hline $\begin{array}{l}\text { Genotypes + } \\
\text { Checks } \\
\text { (Eliminating } \\
\text { Blocks) }\end{array}$ & 98 & $18627.99 * *$ & 0.04 & $0.01 *$ & $22.67 * * *$ & 1.31 & 0.74 & 189.75 & $253.25^{*}$ & $7014.33^{*}$ \\
\hline Checks & 2 & 8470.06 & $0.23 * *$ & $0.05 * *$ & 0.01 & 0.23 & 1.17 & 79.43 & $995.05^{* *}$ & $\begin{array}{c}32236.22 * \\
*\end{array}$ \\
\hline $\begin{array}{l}\text { Checks +Gen vs. } \\
\text { Gen. }\end{array}$ & 96 & $18839.62 * *$ & 0.04 & $0.01 *$ & $23.14 * * *$ & 1.34 & 0.73 & 192.04 & $237.80 *$ & 6488.88 \\
\hline Error & 10 & 2702.31 & 0.03 & 0.00 & 0.00 & 0.82 & 0.49 & 173.59 & 71.43 & 2607.14 \\
\hline $\begin{array}{l}\text { Block (eliminating } \\
\text { Check+ Genotypes) }\end{array}$ & 5 & 903.55 & 0.01 & 0.00 & 0.01 & 1.00 & 0.49 & 79.85 & 124.31 & 3828.12 \\
\hline $\begin{array}{l}\text { Entries (Ignoring } \\
\text { Blocks) }\end{array}$ & 98 & $21524.01 * * *$ & 0.05 & $0.01 * *$ & $23.79 * * *$ & 1.38 & 0.74 & 227.88 & $260.38^{*}$ & 6913.94* \\
\hline Checks & 2 & 8470.06 & $0.23 * *$ & $0.05 * *$ & 0.01 & 0.23 & 1.17 & 79.43 & $995.05^{* *}$ & $\begin{array}{c}32236.22 * \\
*\end{array}$ \\
\hline Genotypes & 95 & $20243.29 * * *$ & 0.04 & $0.01 *$ & $24.52 * * *$ & 1.41 & 0.73 & 230.83 & $245.16^{*}$ & 6453.08 \\
\hline $\begin{array}{l}\text { Checks vs. } \\
\text { Genotypes }\end{array}$ & 1 & $169300.25^{* * *}$ & 0.00 & $0.15^{* * *}$ & $2.24 * * *$ & 1.06 & 0.79 & 244.47 & 237.08 & 50.75 \\
\hline Error & 10 & 2702.31 & 0.03 & 0.00 & 0.00 & 0.82 & 0.49 & 173.59 & 71.43 & 2607.14 \\
\hline
\end{tabular}


Table.4 Mean, range, Genetic variability and heritability components for Quantitative traits in carrot

\begin{tabular}{|c|c|c|c|c|c|c|c|}
\hline Traits & Mean \pm SEm & Min & Max & GCV & PCV & $\begin{array}{c}\mathbf{h}^{2} \\
\text { b.s }\end{array}$ & $\begin{array}{l}\text { GAM } \\
(5 \%)\end{array}$ \\
\hline Days to Maturity & $72.79 \pm 1.08$ & 46.00 & 94.00 & 12.23 & 13.74 & 0.79 & 22.43 \\
\hline No. of Petioles & $10.84 \pm 0.38$ & 6.60 & 28.80 & 31.11 & 31.99 & 0.94 & 62.31 \\
\hline Shoulder Length (cm) & $0.96 \pm 0.02$ & 0.10 & 1.57 & 17.78 & 23.44 & 0.58 & 27.77 \\
\hline Plant Height (cm) & $51.80 \pm 0.96$ & 30.50 & 72.80 & 13.71 & 17.52 & 0.61 & 22.1 \\
\hline Root Length(cm) & $17.51 \pm 0.56$ & 10.38 & 59.34 & 25.33 & 29.72 & 0.73 & 44.47 \\
\hline Petiole Length(cm) & $13.70 \pm 0.55$ & 6.50 & 50.50 & 35.46 & 37.24 & 0.91 & 69.53 \\
\hline Root width (mm) & $18.28 \pm 0.33$ & 11.56 & 31.64 & 14.83 & 16.66 & 0.79 & 27.21 \\
\hline Shoulder Width (mm) & $24.79 \pm 0.63$ & 11.69 & 40.43 & 19.22 & 23.69 & 0.66 & 32.11 \\
\hline $\begin{array}{l}\text { Vegetative weight of } \\
\text { single plant (g) }\end{array}$ & $48.09 \pm 3.10$ & 6.00 & 173.60 & 55.71 & 59.62 & 0.87 & 107.22 \\
\hline $\begin{array}{l}\text { Five plants vegetative } \\
\text { weight (g) }\end{array}$ & $230.70 \pm 15.24$ & 32.00 & 842.00 & 54.30 & 58.87 & 0.85 & 103.19 \\
\hline Xylem Width (mm) & $0.76 \pm 0.02$ & 0.40 & 1.44 & 15.34 & 26.90 & 0.33 & 18.02 \\
\hline Phloem Width (mm) & $0.45 \pm 0.01$ & 0.23 & 0.86 & 19.82 & 23.92 & 0.69 & 33.84 \\
\hline Harvest Index & $0.50 \pm 0.01$ & 0.27 & 0.84 & 46.18 & 46.23 & 0.99 & 94.70 \\
\hline $\begin{array}{l}\text { Total Soluble Solids } \\
\left({ }^{0} \text { Brix }\right)\end{array}$ & $7.77 \pm 0.13$ & 4.75 & 10.30 & 9.21 & 14.86 & 0.38 & 11.75 \\
\hline Reducing Sugars (\%) & $4.79 \pm 0.09$ & 2.99 & 6.94 & 9.63 & 17.47 & 0.30 & 10.92 \\
\hline Beta Carotene $(\mu \mathrm{g} / \mathrm{gm})$ & $22.19 \pm 1.71$ & 2.50 & 79.33 & 32.15 & 67.81 & 0.22 & 31.41 \\
\hline $\begin{array}{l}\text { Root Weight of } \\
\text { individual Plant (g) }\end{array}$ & $42.72 \pm 1.60$ & 16.00 & 97.60 & 28.94 & 35.05 & 0.69 & 49.21 \\
\hline $\begin{array}{l}\text { Five Plants Root } \\
\text { Weight (g) }\end{array}$ & $205.20 \pm 8.43$ & 54.00 & 470.00 & 28.82 & 38.43 & 0.56 & 44.72 \\
\hline
\end{tabular}

Heritability estimate in broad sense alone, does not serve as the true indicator of genetic potentiality of the genotype since the scope is restricted by their interaction with environment. Hence, it is advisable to consider the predicted genetic advance as per cent of mean along with heritability estimate as a reliable tool in selection programme (Johnson et al., 1955).

Hence, both heritability and genetic advance as per cent of mean are determined to get a clear picture of the scope of improvement in various characters through selection. The extent of heritability >60.0\% (>0.60) is considered to be high and in the present investigation, few traits especially the plant morphological traits (except xylem width and five plants root weight) showed very high heritability. Although for the biochemical components, higher heritability is expected, but in the present investigation, these traits showed moderate heritability as depicted by their moderate PCV but lower GCV indicating that, the expression of these traits are highly influenced by temperature, soil conditions as well as other environmental factors. Among the 18 traits studied, except beta carotene content, reducing sugars and the root width, almost all the traits showed higher GAM, where as in the farmer mentioned traits, the GAM was lower. 
In the present study, high heritability was observed for harvest index, number of petioles, petiole length, vegetative weight, root length and root diameter. High heritability in broad sense indicated that large proportion of phenotypic variance was attributable to the genotypic variance and that these character differences among the genotypes were real and showed that the above mentioned traits with high heritability values were less influenced by the environment. The above findings are in close association with those of Brar and Sukhija (1981) and Tewatia and Dudi (1999) who reported high heritability for leaf length and root weight. High heritability for the characters controlled by polygenes might be useful to plant breeder for making effective selection.

Genetic advance expressed as percentage of mean was relatively high for vegetative weight, harvest index, number of petioles and petiole length.Low heritability was observed for root length. Genetic advance expressed as percentage of mean was relatively low for the characters viz., plant height, root length and inner core (xylem) diameter. The results are in line with the findings of Amin and Singla (2010) and Ullah et al., (2010), Yadav et al., (2009) for root length. Since genetic coefficient of variability, phenotypic coefficient of variability and heritability estimates determine the component of heritable variation and genetic advance measures the extent of its suitability under selection, all these parameters should be considered simultaneously so as to bring effective improvement in yield and other characters.

High heritability coupled with high genetic advance indicates the role of additive gene action (Panse 1957) and consequently a high genetic gain is expected from selection under such situation. Hence, the traits like harvest index, number of petioles, petiole length, vegetative weight which exhibited high heritability coupled with high to moderate genetic advance, are likely to respond better to selection. Shoulder width, phloem width, root weight had moderate heritability associated with moderate genetic advance indicating thereby, that the selection based on phenotypic performance could be effective for the improvement of these traits. Days to maturity, plant height, root length and root diameter had moderate heritability associated with low genetic advance, suggesting thereby that inheritance of these traits was controlled by epistatic interaction.

Moderate heritability coupled with low genetic advance for root length and root diameter have also been reported by Brar and Sukhija (1981) and Saini et al., (1981), respectively, which are same as the present findings. Low heritability in combination with low genetic advance was observed for total soluble solids, beta carotenoid, reducing sugars, these characters are more under the influence of non-additive gene action and environment and do not respond to selection.

In the present investigation, harvest index, number of petioles, petiole length, vegetative weight accounted for the higher heritability and higher genetic advance. So these characters can be easily improved by selection methods. High heritability coupled with moderate genetic advance was expressed in Shoulder width, phloem width, root weight. So these characters can be partially improved by selection methods.

Genetic diversity studies revealed that there was no parallelism between genetic and morphological diversities in the present material and ssufficient variability existed in the material under study, which could be exploited either through selection or hybridization. 


\section{Acknowledgment}

This is a part of the research carried out from the funding of DBT (BIOCARE) File No: 102/IFD/SAN/3308/2014-15

\section{References}

Amin, A. and Singla, J., 2010. Genetic variability, heritability and genetic advance studies in carrot (Daucus carota var. sativa L.). Electr. J. Pl. Breed., 1 (6): 1504-1508.

Banga, O., 1957, Origin of the European cultivated carrot. Euphytica, 6: 54-63

Brar, J.S. and Sukhija, B.S., 1981, Study on genetic parameters in carrot (Daucus carrota L.). J. Res. Punjab Agric. Univ., 18 (3): 287 - 291.

Fisher, R. A., 1918, The correlation between the relatives on the supposition of Mendelian inheritance. Translated from Royal Society of Edinburgti, 52: 399-44

Gupta, A. J., Verma, T. S., Sethi, S. and Singh, G., 2006, Evaluation of European carrot genotypes including F1 hybrids for their root quality, yield and nutritive characters. Indian J. Hort., 63 (1): 48-52.

Harborne, J. B., 1973, Phytochemical Methods. In: Harborne JB (eds) A Guide to Modern Techniques of Plant Analysis, Chapman and Hall, London, pp. 33-80.

Iorizzo, M., Shelby, E., Douglas, S., Zeng, P., Pimchanok, S., Jiaying, H., Bowman, M., Marina, I., Walter, S., Cavagnaro, P., Yildiz, A., Moranska, E., Grzebelus E., Grzebelus D., Ashrafi H., Zhijun Z., Shifeng C, Spooner D., Allen Van D. and Philipp Simon, 2016, A highquality carrot genome assembly provides new insights into carotenoid accumulation and asteroid genome evolution. Nature Genet., doi:10.1038/ng.3565.
IPGRI, 1998, Descriptors for Wild \& Cultivated Carrots. International Plant Genetic Resources Institute, Rome, Italy, p. 65.

Johnson, H. W., Robinson, H. F. and Comstock, F., 1955, Genotypic and phenotypic correlation in soybean and their implications in selection. Agronomy J., 47: 477-483.

Nicolle, C., Simon, G., Rock, E., Amouroux, P., Remesy, C., 2004, Genetic variability influences carotenoid, vitamin, phenolic, and mineral content in white, yellow, purple, orange, and dark-orange carrot cultivars. $J$. American. Soc. Hort. Sci., 129: 523.

Panse, V. G., 1957. Genetics of quantitative characters in relation to plant breeding. Indian J. Genet. Plant Breed., 17: 318328

Peirce, L. C., 1987, Vegetable characteristics, Production and Marketing. John Wiley and Sons. Inc., New York, 251-252.

Peterson, C. E., Simon, P. W., Rubatzky, V. E. and Strandberg, J. O., 1988, Beta 111 Carrot. Horl. Sci. 22 (9): 41-97.

Prasad, A. and Prasad, R., 1980.Genetic variability and correlation in carrot. Ind J Agril Sci., 50 (7): 555-557.

Rabbani, N. A., Murakami, Y., Kuginuki, Y. and Takayanagi, K., 1998, Genetic variation in radish (Raphanus sativus L.) germplasm. Genetic Res. \& Crop Evol., 45(4): 307-316.

Rahman, M. A., Alam, M. S., Ahmed, Q. N., Khan, M. A. I. and Mahbub, A. A., 2003, Genetic analysis on yield and its component traits of tomato (Lycopersicon esculentum Mill.). Agriculturists 1(1): 21-26.

Rubatzky, V. E, Quiros C. F. and Simon P. W, 1999, Carrots and related vegetable Umbelliferae. CABI, New York.

Saini, S. S., Koria, B. N. and Rastogi K. B., 1981, Genetic variability and genotype $\mathrm{x}$ environment interaction in carrot 
(Daucus carota L.). Veg. Sci., 8 (2): 9399

Singh, Y. and Mittal, P. 2003, Variability studies in ginger (Gingiber officinale R.) under humid sub-temperate conditions. Crop Research 25 (1): 194.

Sivasubramanian, S. and Menon, P., M., 1973, Genotypic and phenotypic variability in rice. Madras Agric. J., 60 (9-13): 1093-1096.

Surles, R. L., Weng, N., Simon, P. W. and Tanumihardjo, S. A., 2004, Carotenoid profiles and consumer sensory evaluation of specialty carrots (Daucus carota. L.) of various colors. J. Agric. Food Chem., 52: 3417-3421.

Tewatia, A. S. and Dudi, B.S., 1999. Genetic variability and heritability studies in carrot (Daucus carota L.). Ann. Agric. Bio. Res., 4(2): 213-214.
Ullah, M. Z., Hasan, M. J., Rahman, A. H. M. A. and Saki, A. I., 2010, Genetic variability, character association and path co-efficient analysis in radish (Raphanus sativus L.). Agriculturists, 8(2): 22-27.

Vavilov, N. I., 1949. The origin, variation, immunity and breeding of cultivated plants. Chron. Bot., 13: 1-366.

Yadav, M., Tirkey, S., Singh, D. B, Chaudhary, R, Roshan R. K, and Pebam N. 2009. Genetic variability, correlation coefficient and path analysis in carrot. Indian J. Horti., 66 (3): 315-318.

Yadav, M., Tirkey, S., Singh, D. B, Chaudhary, R, Roshan R. K, and Pebam N. 2009. Genetic variability, correlation coefficient and path analysis in carrot. Indian J. Horti., 66 (3): 315-318.

\section{How to cite this article:}

Chaitra C. Kulkarni, D.S. Manikanta, Chaitra A. Poleshi, Sarvamangala S. Cholin, G. Raghavendra, D.S. Ambika and Patil, B.B. 2019. Genetic Variability, Heritability and Genetic Advance for Economic Root Traits in Asiatic and European Type Carrot Germplasm Lines (Daucus carota L.). Int.J.Curr.Microbiol.App.Sci. 8(07): 2553-2563. doi: https://doi.org/10.20546/ijcmas.2019.807.315 